\title{
APPLICATION OF SYNCHRONOUS GRID-CONNECTED CONTROLLER IN THE WIND- SOLAR-STORAGE MICRO GRID
}

\author{
Hua Li, Yongfeng Ren, Le Li, Zhenpeng Luo
} Recently, there has been an increasing interest in using distributed generators (DG) not only to inject power into the grid, but also to enhance the power quality. In this study, a space voltage pulse width modulation (SVPWM) control method is proposed for a synchronous grid-connected controller in a wind-solar-storage micro grid. This method is based on the appropriate topology of the synchronous controller. The wind-solar-storage micro grid is controlled to reconnect to the grid synchronously while maintance or repair is being completed to the power source equation DG at some point, the voltage difference that exists between DG and both sides of the node, a large and sudden electrical surge when DG is reconnected to the grid. It also affects the normal work of the other DG and power quality of a necessary load, and could even seriously paralyze the whole system. So, the topological structure and control method of the synchronous grid-connected controller are discussed in detail and simulation results are presented. The results demonstrate the effectiveness of the proposed method in the synchronous grid-connected controller for the wind-solar-storage micro grid.

Keywords: distributed generator (DG); micro grid; SVPWM; synchronous grid-connected controller

\section{Primjena sinkronog mrežno povezanog upravljačkog uređaja u mikro mrežu pohrane energije vjetra-sunca}

Izvorni znanstveni članak

U zadnje je vrijeme poraslo zanimanje za uporabu raspodjelnih generatora (DG) ne samo za uključivanje energije u mrežu već i za poboljšanje kvalitete energije. U ovom se radu predlaže metoda regulacije SVPWM (space voltage pulse width modulation) za sinkroni mrežno povezani upravljački uređaj u mikro mrežu pohrane energije vjetra-sunca. Ta se metoda zasniva na odgovarajućoj topologiji sinkronog upravljačkog uređaja. Mikro mreža pohrane energije vjetra-sunca upravlja se tako da se istovremeno uključi u mrežu dok se ne završi održavanje ili popravi ujednačeni izvor energije DG u nekoj točki, razlika u naponu koja postoji između DG i obje strane čvora, naglo povećanje električne energije kada se DG ponovo uključuje u mrežu. To također utječe na normalan rad drugog DG i na kvalitetu potrebnog opterećenja, a moglo bi čak i ozbiljno paralizirati čitavi sustav. Stoga se topološka struktura i kontrolne metode sinkronog upravljačkog uređaja detaljno analiziraju i prezentiraju se rezultati simulacije. Prezentirani rezultati pokazuju učinkovitost predložene metode sinkronog upravljačkog uređaja povezanog s rešetkom u mikro mrežu pohrane energije vjetra-sunca.

Ključne riječi: raspodjelni generator (DG); mikro mreža; sinkroni mrě̌no povezani upravljački uređaj; SVPWM

\section{Introduction}

The distributed generation system (DG) is becoming a vital development direction in many countries and regions. Accompanying China's rapid economy development is in greater demand, advancing year by year, for electric power requiring large and more diverse energy sources, and resulting in conflicts with environmental concerns that loom large[1, 2]. Integrating the micro grid system and smart grid is an effective approach to make the best of distributed generation [3]. However, the distributed renewable energy power generation from renewable energy sources have exhibited intermitent and random characteristics that restrict its power generation capability and its operating stability $[4,5]$. The micro grid can join the distributed generation and energy storage equipment together through an advanced control system, and form a controllable cell. It not only operates with the distribution power system connection grid, but also can operate independant of the grid $[6,7]$. The micro grid connection may integrate smoothly into the distributed generation and bring remarkable value into the power supply company and the individual user [8]. The synchronous grid-connected controller as a bridge between the grid and micro power supply, can play a crucial role for the stable operation of the whole system and the effective distribution of power.

The SVPWM (space voltage pulse width modulation) method is an ideal method to content the needs of synchronization grid-connected controller for the DG to reconnect to the grid. The structure of the parallel synchronous grid-connected controller is established in this paper. The space voltage vector control principle is analyzed based on the three-phase voltage source inverter topological structure. The voltage space vector control method is applied to process the dynamic real-time simulation for the synchronous grid-connected controller, and its performance was analyzed. Finally, the micro grid system is studied via using the SVPWM synchronization grid-connected controller. The simulation results demonstrate the viability and effectiveness of the proposed method of reconnecting the DG to the grid.

\section{Structure of the wind-solar-storage micro grid system}

The wind-solar-storage micro grid system structure is shown in Fig. 1, where the micro grid is connected to the medium voltage (MV) alternating current distribution network by ac/dc or dc/ac converters $[9,10]$. All of these converters use SVPWM control. Batteries are positioned at the wind turbine and photovoltaic (PV) array export outlet for the power to stabilize the grid and islanding operation using a given voltage and frequency control [11 $\div 13$ ]. Meanwhile, the batteries can absorb or recharge the power shortfall of wind and sun in order to maintain the power balance of the entire system. Load 1 and 2 are sensitivity load, which should guarantee the reliability of the power supply when the micro grid system is in operation. The normal load 3 can be removed when necessary. 


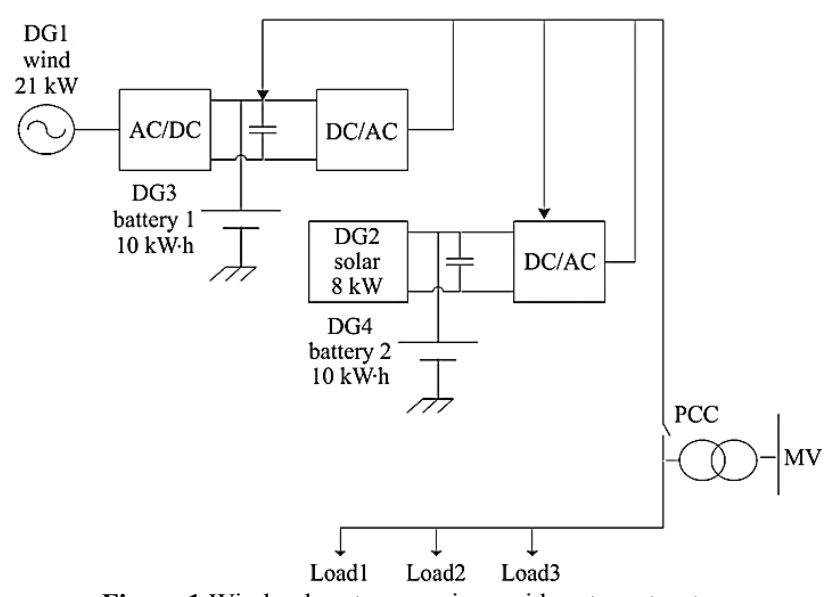

Figure 1 Wind-solar-storage micro grid system structure

\section{Model of synchronous grid-connected controller and SVPWM control strategy \\ 3.1 Space voltage vector control principle}

The space voltage vector control has been widely used in motor system [14, 15], and in new energy sources power generation and new type of converter in recent years $[16,17]$. It is applied to parallel synchronous gridconnected controller in this paper. A typical voltage source inverter structure is shown in Fig. 2.

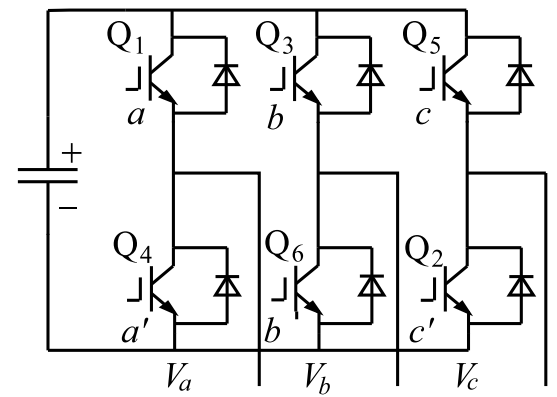

Figure 2 Structure of three-phase source converter

In Fig. 2, $V_{a}, V_{b}, V_{c}$ is the output voltage of the inverter. $\mathrm{Q}_{1}$ to $\mathrm{Q}_{6}$ are the six inverter power transistors, which are controlled by the six control signals $a, a^{\prime}, b, b^{\prime}$, $c, c^{\prime}$. The upper part of a power transistor of inverter bridge is opened, $a, b$ or $c$ is equal to 1 , and the lower part of the relavant power transistor is shut down $a^{\prime}=b^{\prime}=c^{\prime}=$ 0 . The output voltage of $V_{a}, V_{b}, V_{c}$ is determined through $\mathrm{Q}_{1}, \mathrm{Q}_{3}$ and $\mathrm{Q}_{5}$ power transistor switch state. The relationships among the line voltage vector $\left[V_{a b} V_{b c} V_{c a}\right]^{\mathrm{T}}$, phase voltage vector $\left[\begin{array}{lll}V_{a} & V_{b} & V_{c}\end{array}\right]^{\mathrm{T}}$, switch variable vector

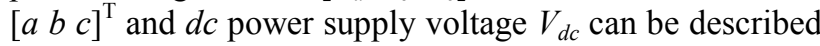
as

$\left[\begin{array}{l}V_{a b} \\ V_{b c} \\ V_{c a}\end{array}\right]=V_{d c}\left[\begin{array}{ccc}1 & -1 & 0 \\ 0 & 1 & -1 \\ -1 & 0 & 1\end{array}\right]\left[\begin{array}{l}a \\ b \\ c\end{array}\right]$.

$\left[\begin{array}{l}V_{a} \\ V_{b} \\ V_{c}\end{array}\right]=\frac{1}{3} V_{d c}\left[\begin{array}{ccc}2 & -1 & -1 \\ -1 & 2 & -1 \\ -1 & -1 & 2\end{array}\right]\left[\begin{array}{l}a \\ b \\ c\end{array}\right]$

According to Eq. (1) and Eq. (2), the switch has eight possible combination modes when the inverter is working.
The relationship between the switching states and voltage of the inverter is described according to the $V_{d c}$ as shown in Tab. 1.

Table 1 Relationship between switching states and voltage of converter

\begin{tabular}{|c|c|c|c|c|c|c|c|c|}
\hline \multicolumn{3}{|c|}{ Switch state } & \multicolumn{3}{c|}{ Phase voltage } & \multicolumn{3}{c|}{ Line voltage } \\
\hline$a$ & $b$ & $c$ & $V_{a}$ & $V_{b}$ & $V_{c}$ & $V_{a b}$ & $V_{b c}$ & $V_{c a}$ \\
\hline 0 & 0 & 0 & 0 & 0 & 0 & 0 & 0 & 0 \\
\hline 0 & 0 & 1 & $-1 / 3$ & $-1 / 3$ & $2 / 3$ & 0 & -1 & 1 \\
\hline 0 & 1 & 0 & $-1 / 3$ & $2 / 3$ & $-1 / 3$ & -1 & 1 & 0 \\
\hline 0 & 1 & 1 & $-2 / 3$ & $1 / 3$ & $1 / 3$ & -1 & 0 & 1 \\
\hline 1 & 0 & 0 & $2 / 3$ & $-1 / 3$ & $-1 / 3$ & 1 & 0 & -1 \\
\hline 1 & 0 & 1 & $1 / 3$ & $-2 / 3$ & $1 / 3$ & 1 & -1 & 0 \\
\hline 1 & 1 & 0 & $1 / 3$ & $1 / 3$ & $-2 / 3$ & 0 & 1 & -1 \\
\hline 1 & 1 & 1 & 0 & 0 & 0 & 0 & 0 & 0 \\
\hline
\end{tabular}

In the $d$ and $q$ axis coordinate system, the three phase voltage corresponding to the output variables can be expressed as:

$\left[\begin{array}{l}V_{d} \\ V_{q}\end{array}\right]=\frac{2}{3}\left[\begin{array}{ccc}1 & -\frac{1}{2} & -\frac{1}{2} \\ 0 & \frac{\sqrt{3}}{2} & -\frac{\sqrt{3}}{2}\end{array}\right]\left[\begin{array}{l}V_{a} \\ V_{b} \\ V_{c}\end{array}\right]$.

According to Eq. (3), the eight combinations of switch state are mapped to the $d, q$ axis coordinate system, the eight vectors are called the basic space vector, and the space is divided into six sectors, as shown in Fig. 3.

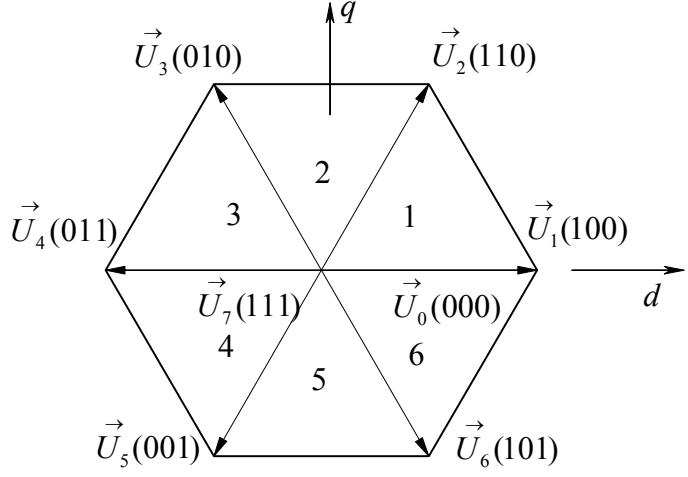

Figure 3 Basic voltage space vector

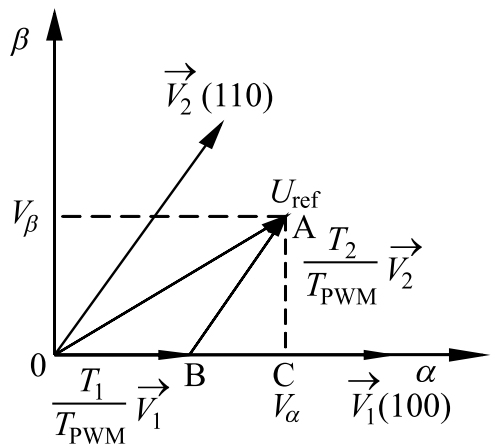

Figure 4 First sector voltage vector composite

The purpose of the SVPWM control is accomplished through a combination of basic space vector corresponding to a given reference voltage vector $U_{\text {ref }}$. Because the inverter can produce only eight basic voltage vector expressions, after a known reference voltage vector is determined according to the principle of volt-second 
characteristics it is equal to the output voltage vector approximation to the reference voltage vector. The synthesized voltage vector $U_{\text {ref }}$ is decomposed in the first sector, as shown in Fig. 4. $U_{\text {ref }}$ is expressed with $U_{1}$ and $U_{2}$, expressed as:

$\left\{\begin{array}{l}T=T_{1}+T_{2}+T_{0} \\ U_{\text {ref }} T=U_{1} T_{1}+U_{2} T_{2} .\end{array}\right.$

Voltage and action time relationship in the $d q$ coordinate system can be described as

$$
\left\{\begin{array}{l}
\left|U_{1}\right| T_{1}+\left|U_{2}\right| T_{2} \cos 60^{\circ}=V_{d} T \\
\left|U_{2}\right| T_{2} \sin 60^{\circ}=V_{q} T .
\end{array}\right.
$$

In the equation, $T$ is the switching period, $T_{1}, T_{2}$ is the action time of $U_{1}$ and $U_{2}, T_{0}$ is the zero vector function time. All the amplitude of $U_{1}$ and $U_{2}$ is $2 / 3 V_{d c}$. Where the equation passed series of mathematical calculations, can be expressed as:

$$
\left\{\begin{array}{l}
T_{1}=\frac{T\left(\frac{3}{2} V_{d}-\frac{\sqrt{3}}{2} V_{q}\right)}{V_{d c}} \\
T_{2}=\frac{\sqrt{3} V_{q} T}{V_{d c}} .
\end{array}\right.
$$

The function time of the other sectors basic space voltage vector was calculated similarly, and it must be a saturated judgment, that is, if $T_{1}+T_{2}>T$, that pick up

$$
\left\{\begin{array}{l}
T_{1}=\frac{T_{1} T}{T_{1}+T_{2}} \\
T_{2}=\frac{T_{2} T}{T_{1}+T_{2}}
\end{array}\right.
$$

Sectors are judged via set $N=A+2 B+4 C$, and the definition is as follows:

$$
\left\{\begin{array}{l}
X=\frac{\sqrt{3} V_{q} T}{V_{d c}} \\
Y=\frac{\left(\frac{\sqrt{3}}{2} V_{q}+\frac{3}{2} V_{d}\right) T}{V_{d c}} \\
Z=\frac{\left(\frac{\sqrt{3}}{2} V_{q}-\frac{3}{2} V_{d}\right) T}{V_{d c}},
\end{array}\right.
$$

If $V_{q}>0$, the $A=1$, otherwise $A=0$; if $\sqrt{3} V_{d}-V_{q}>0$, the $B=1$, otherwise $B=0$; if $\sqrt{3} V_{d}+V_{q}<0$, the $C=1$, otherwise $C=0$. The relationship of $N$, sector number and vector effect time, is shown in Tab. 2 according to the above analysis.

Table 2 Relation between $N$, sectors, $T_{1}$ and $T_{2}$
\begin{tabular}{|c|c|c|c|c|c|c|}
\hline$N$ & 3 & 1 & 5 & 4 & 6 & 2 \\
\hline Sector & 1 & 2 & 3 & 4 & 5 & 6 \\
\hline$T_{1}$ & $-Z$ & $Z$ & $X$ & $-X$ & $-Y$ & $Y$ \\
\hline$T_{2}$ & $X$ & $Y$ & $-Y$ & $Z$ & $-Z$ & $-X$ \\
\hline
\end{tabular}

In sector 1 , for example, the active time of zero vector 000 and 111 is equal in an assumed switching cycle, the symmetric PWM waveform is generated, and each basic space vector effect time is divided into two parts. According to the 000, 100, 110, 111, 110, 100, 110 worked order, only one switch is changed each time, as shown in Fig. 5.

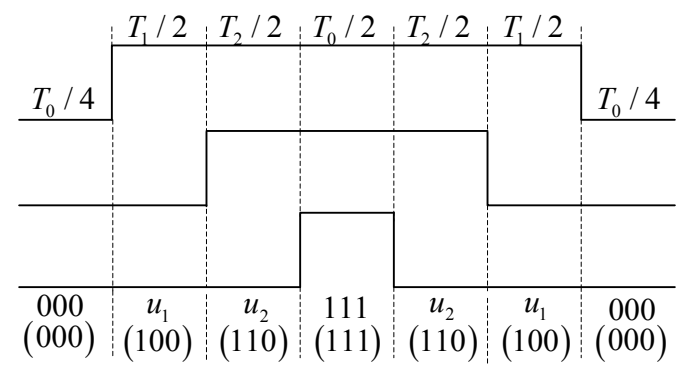

Figure 5 Working waveform of sector 1

The time between sector switch point and zero point is defined $T_{u}, T_{v}, T_{w}$

$\left\{\begin{array}{l}T_{u}=\frac{T-T_{1}-T_{2}}{4} \\ T_{v}=T_{u}+\frac{T_{1}}{2} \\ Z=T_{v}+\frac{T_{2}}{2} .\end{array}\right.$

$T_{1}$ corresponds to the first vector role time value, $T_{2}$ corresponds to another nonzero vector role time value. So, $T_{u}, T_{v}, T_{w}$ is assigned to each sector of the waveform in one switching cycle. $T_{u}$ is distributed to the duty ratio maximum phase, and $T_{w}$ is distributed to the minimum phase. The switch points $T_{C M 1}, T_{C M 2}, T_{C M 3}$ can be obtained through the various sectors worked waveform, displayed in Tab. 3.

Table 3 Value of the points for switching
\begin{tabular}{|c|c|c|c|c|c|c|}
\hline$N$ & 1 & 2 & 3 & 4 & 5 & 6 \\
\hline$T_{C M 1}$ & $T_{v}$ & $T_{u}$ & $T_{u}$ & $T_{w}$ & $T_{w}$ & $T_{v}$ \\
\hline$T_{C M 2}$ & $T_{u}$ & $T_{w}$ & $T_{v}$ & $T_{v}$ & $T_{u}$ & $T_{w}$ \\
\hline$T_{C M 3}$ & $T_{w}$ & $T_{v}$ & $T_{w}$ & $T_{u}$ & $T_{v}$ & $T_{u}$ \\
\hline
\end{tabular}

\subsection{Parallel synchronous grid-connected controller of SVPWM control technology}

In the wind-solar-storage micro grid, distributed power from a particular type of power source must occassionally exit the island operation model of the micro grid system because of a possible malfunction or planned maintenance, etc. After completing the maintenance or repair, the DG is requested to connect to the island operation of the micro grid system at some point. But due to the voltage difference between the DG and the node at each side of the grid, there can be a large shock to the system when hooked up to the micro grid at that moment. 
This state not only affects the normal running of the other DG and the power quality of its load but also can temporarily seriously paralyze the whole system. Therefore, the application of synchronous grid-connected controller is proposed for the wind-solar-storage micro grid system $[18 \div 20]$. The schematic diagram of the parallel synchronous grid-connected controller is shown as in Fig. 6.

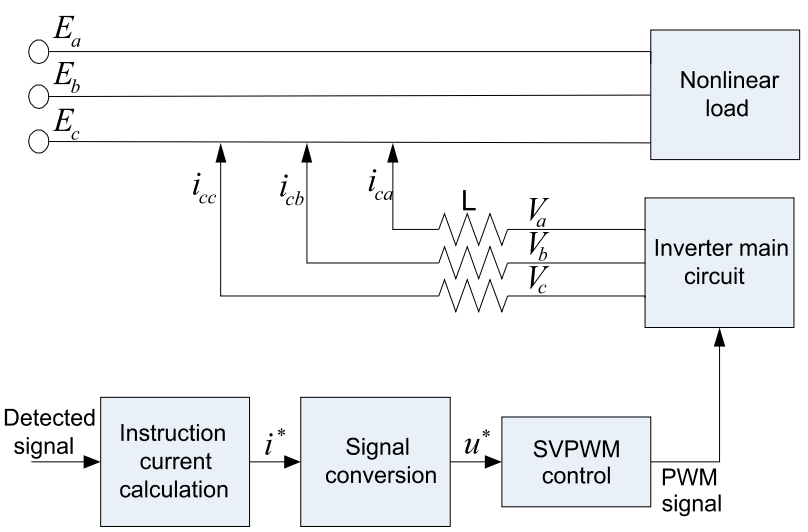

Figure 6 Parallel synchronization grid-connected

SVPWM plays the role of voltage control, but the obtained instruction is the current signal through the instantaneous reactive power theory, which requires the instructions of the current signal to be converted into a voltage signal. A simple and rapid approximate algorithm is adopted in this paper. The equation obtained from Fig. 6 is as follows:

$L \frac{\mathrm{d} i_{c a}}{\mathrm{~d} t}+R i_{c a}=V_{a}-E_{a}$,

$L \frac{\mathrm{d} i_{c b}}{\mathrm{~d} t}+R i_{c b}=V_{b}-E_{b}$,

$L \frac{\mathrm{d} i_{c c}}{\mathrm{~d} t}+R i_{c c}=V_{c}-E_{c}$.

The control goal is to make the output current $i_{c x}$ equal to the reference current value $i_{c x}^{*}$. Reference voltage vector $V_{x}^{*}$ can be obtained from transforming Eq. (10). The $V_{x}^{*}$ can be expressed as:

$V_{a}^{*}=E_{a}+L \frac{\mathrm{d} i_{c a}^{*}}{\mathrm{~d} t}+R i_{c a}^{*}$

$V_{b}^{*}=E_{b}+L \frac{\mathrm{d} i_{c b}^{*}}{\mathrm{~d} t}+R i_{c b}^{*}$,

$V_{c}^{*}=E_{c}+L \frac{\mathrm{d} i_{c c}^{*}}{\mathrm{~d} t}+R i_{c c}^{*}$

Where Eq. (11) passes a series of discretization mathematical resolving, it can be expressed as:

$$
\begin{aligned}
& V_{a}(k+1)=E_{a}+L \frac{i_{c a}(k+1)-i_{c a}(k)}{T}+R i_{c a}(k+1), \\
& V_{b}(k+1)=E_{b}+L \frac{i_{c b}(k+1)-i_{c b}(k)}{T}+R i_{c b}(k+1), \\
& V_{c}(k+1)=E_{c}+L \frac{i_{c c}(k+1)-i_{c c}(k)}{T}+R i_{c c}(k+1) .
\end{aligned}
$$

So, instructions for the voltage signal are obtained through the current signal from Eqs. (10) $\div(12)$.

\subsection{The synchronous grid-connected controller simulation based on SVPWM}

The model of the SVPWM algorithm includes the vector transformation module, sector judgment module, time module, switch module, PWM generating module, etc. as shown in Fig. 7.

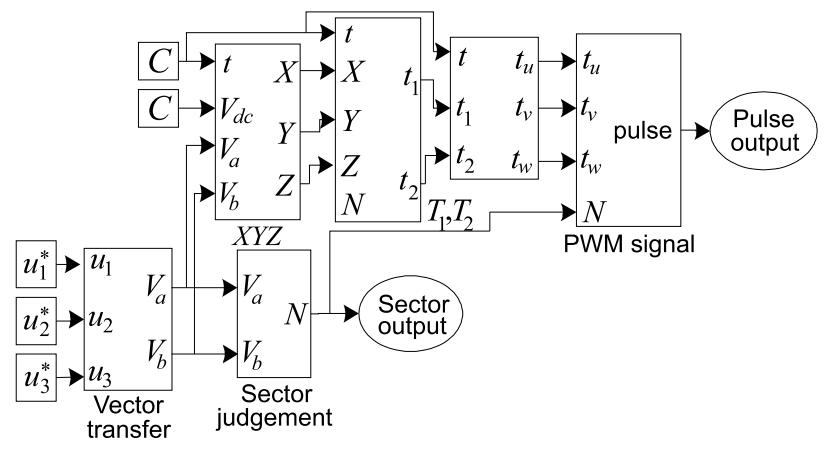

Figure 7 The module of SVPWM strategy controller structure

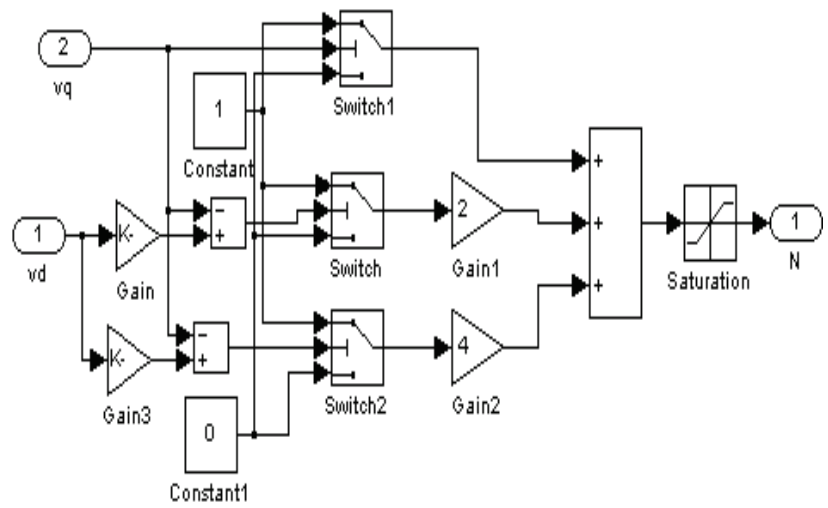

Figure 8 Sector judging model

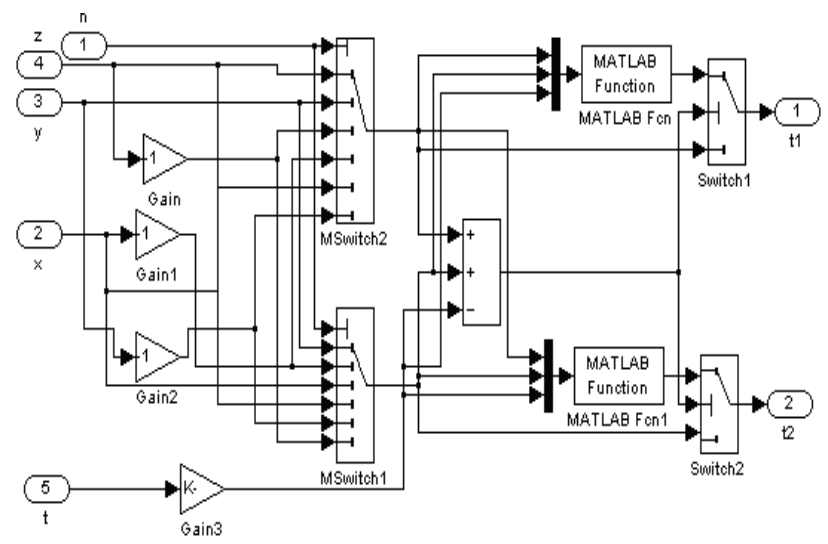

Figure 9 Operating time of each vector calculating model

The sector judgment method is determined according to the instructions voltage signal which processed the $3 / 2$ 
transformation value, as shown in Fig. 8. The simulation model of vector calculation time can be obtained from Eqs. (6) $\div(8)$ and Tab. 2 as shown in Fig. 9.

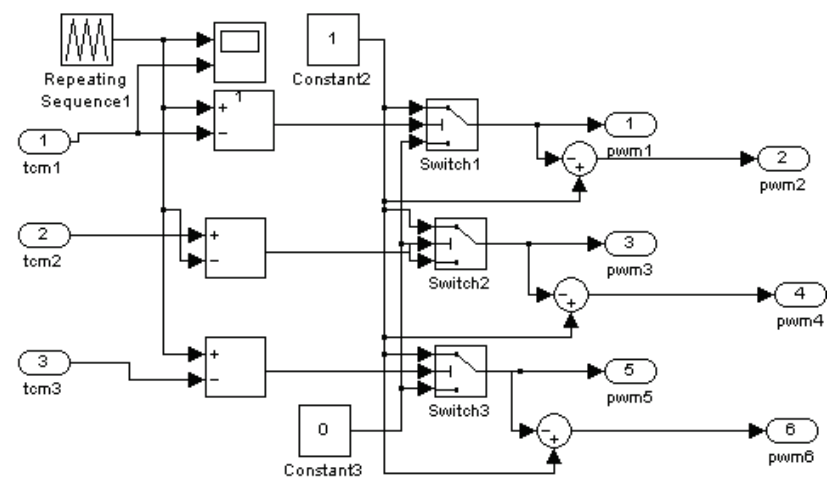

Figure 10 PWM signal generation block of SVPWM method

The vector switch points moment is calculated according to Eq. (9) and Tab. 3, as compared with triangular wave and space vector points. The PWM state is changed as soon as the compared value is equal, as shown in Fig. 10. Simulation waveforms of the SVPWM method for phase A are shown in Fig. 11.

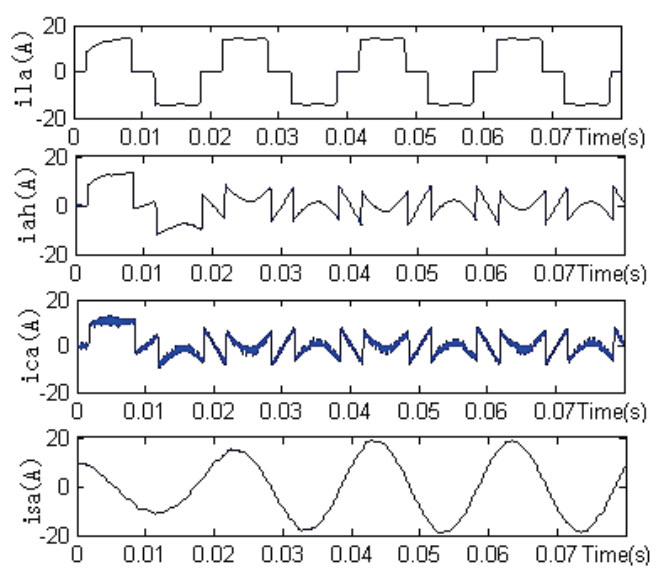

Figure 11 Simulation waveforms of SVPWM method for phase A

Fig. 11 shows the simulation results. The control method of SVPWM control after the control of power supply current is basically similar to the sine wave, which can make the output of the DG and the regional power grid have the same voltage amplitude, phase and frequency, thus realizing the synchronization operation.
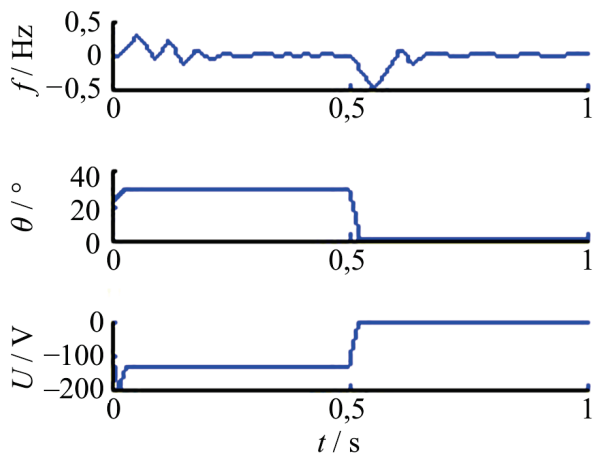

(a) Directly incorporated into the micro grid

\section{Wind-solar-storage micro grid system simulation} results

\subsection{Simulation parameter}

In the sample, the wind power rating is $P_{\mathrm{DG} 1}=21 \mathrm{~kW}$. The rated power of photovoltaic is $P_{\mathrm{DG} 2}=8 \mathrm{~kW}$. The total capacity of batteries 1 and 2 is $10 \mathrm{~kW} \cdot \mathrm{h}$. The active power reference values of ensitive loads 1 and 2 are $11 \mathrm{~kW}$ and $8 \mathrm{~kW}$ respectively. The grid voltage is $380 \mathrm{~V}, 50 \mathrm{~Hz}$. Filtering inductance is $L=2 \mathrm{mH}$. $d c$ side capacitor is $C=$ $220 \mu \mathrm{F}$. $d c$ side voltage is $E=600 \mathrm{~V}$. The power supply equivalent resistance value $R=0,1 \Omega . R / X=0,641 / 0,082$ $\Omega / \mathrm{km}$ is the line parameter.

\subsection{Simulation result}

The micro grid is the island operation mode and $\mathrm{DG}_{3}$ is the disconnected micro grid at below $0,5 \mathrm{~s}$. At $0,5 \mathrm{~s}$, $\mathrm{DG}_{3}$ is reconnected to the micro grid via two methods of direct and synchronous grid-connected controller. Compared with the micro power source $\mathrm{DG}_{3}$ is connected to the micro grid directly and through the synchronous grid-connected controller reconnected to the micro grid. The detailed simulation results are shown in Figs. 12 to 17. The left columns of Figs. $12 \div 17$ describe the situation of $\mathrm{DG}_{3}$ connected to the micro grid directly, and the right columns show the state of $\mathrm{DG}_{3}$ connected to the micro grid through synchronous grid-connected controller.

Fig. 12 is the frequency difference $f$, phase difference $\theta$ and amplitude difference $U$ waveform figure on each side of the switch. Comparing Fig. 12a with Fig. 12b, $f$, $\theta, U$ has clearly decreased in Fig. $12 \mathrm{~b}$, indicating it has satisfied the requirements of synchronous grid-connected controller reconnecting to the micro grid.

Fig. 13 is the waveform of switch point injection to the micro power grid harmonic current. The FTT analysis of the micro power source $\mathrm{DG}_{3}$ connected to the micro grid directly is shown in Fig. 13a, and the FTT analysis through synchronous grid-connected controller reconnected to the micro grid is shown in Fig. 13b. In comparing the two methods the THD of switch point injection harmonic current by grid-connected controller is far less than being connected to the micro grid directly. This waveform verifies that the synchronous gridconnected controller is valid and effective.
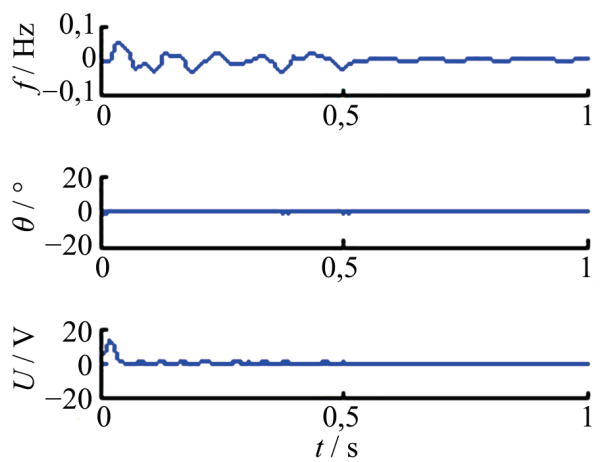

(b) Incorporated into the micro grid using grid-connected controller

Figure 12 On either side of the switch point frequency difference, phase difference and amplitude difference waveform 
The frequency difference $f$, phase difference $\theta$ and amplitude difference $U$ is larger in Fig. 12a than Fig. 12b. And the THD of switch point injection to the micro power grid harmonic current is higher in Fig. 13a than Fig. 13b. So a large current shock $I$ is produced when $D_{3}$ is connected to the micro grid directly as shown in Fig. 14a. Therefore the large power rush is created for other DGs active power $P_{1}, P_{2}, P_{3}, P_{4}$ and reactive power $Q_{1}$, $Q_{2}, Q_{3}, Q_{4}$ at $0,5 \mathrm{~s}$. The active power simulation waveform is shown in Fig. $15 \mathrm{a}$ when $\mathrm{DG}_{3}$ is directly connected to

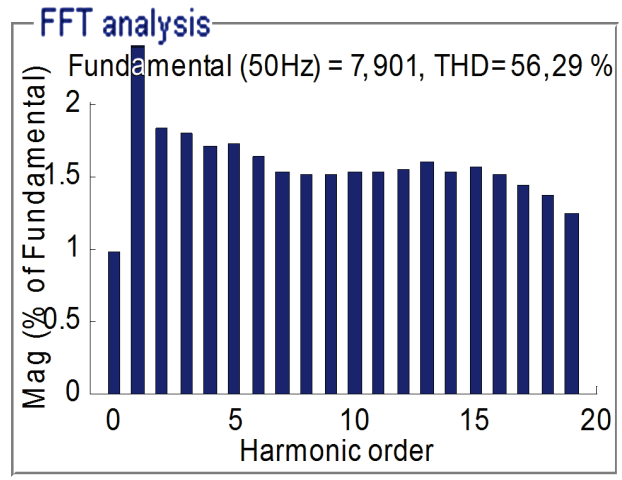

(a) Directly incorporated into the micro grid Figure 13 The waveform of switch point injection to the micro power grid harmonic current

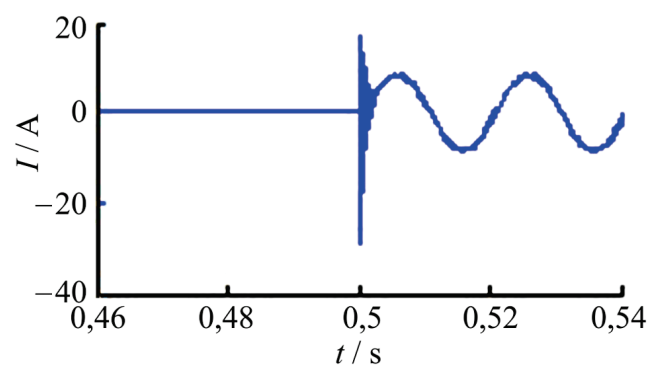

(a) Directly incorporated into the micro grid Figure 14 Injection current waveform of $\mathrm{DG}_{3}$ to micro grid
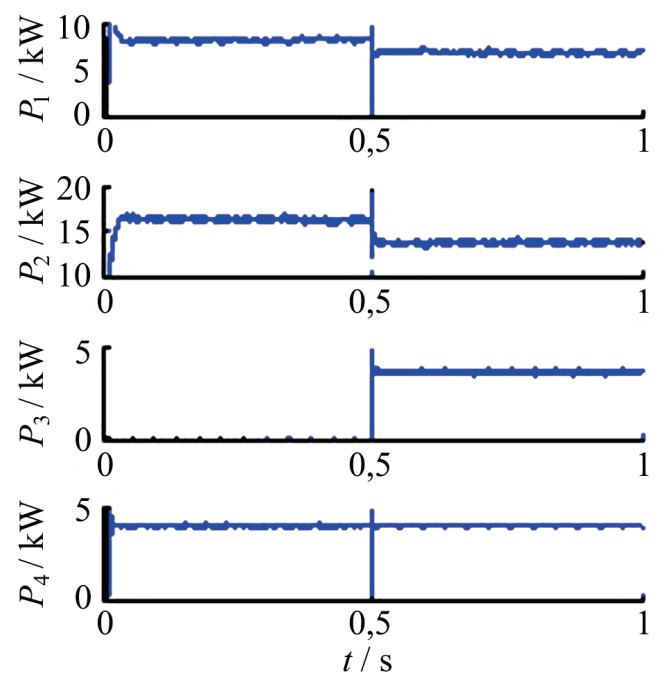

(a) Directly incorporated into the micro grid

Figure 15 The waveform of DG active power

The second method is $\mathrm{DG}_{3}$ being reconnected to the micro grid through the synchronous grid-connected controller at $0,5 \mathrm{~s}$. All of the voltage quality on each side of the switch point and harmonic current of the switch point injection to the micro grid reached the requirement of the synchronous grid-connected controller as seen in the micro grid. The reactive power simulation waveform is shown in Fig. 16 a when $\mathrm{DG}_{3}$ is directly connected to the micro grid. Using this method the important load voltage fluctuations $U_{1}$ and $U_{2}$ are produced when the power source $\mathrm{DG}_{3}$ is reconnected to the micro grid moment. The simulation figure is shown in Fig. 17a, indicating that the method of $\mathrm{DG}_{3}$ being directly connected to the micro grid cannot satisfied the stability and reliability requirements of the important load power supply.

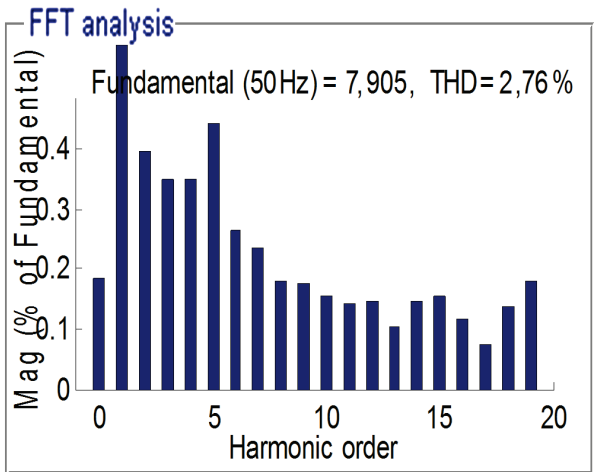

(b) Incorporated into the micro grid using grid-connected controller

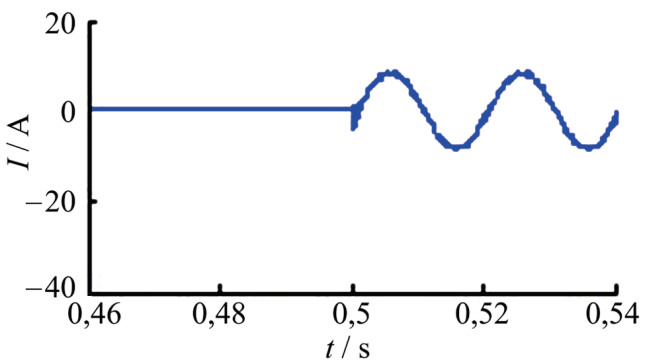

(b) Incorporated into the micro grid using grid-connected controller
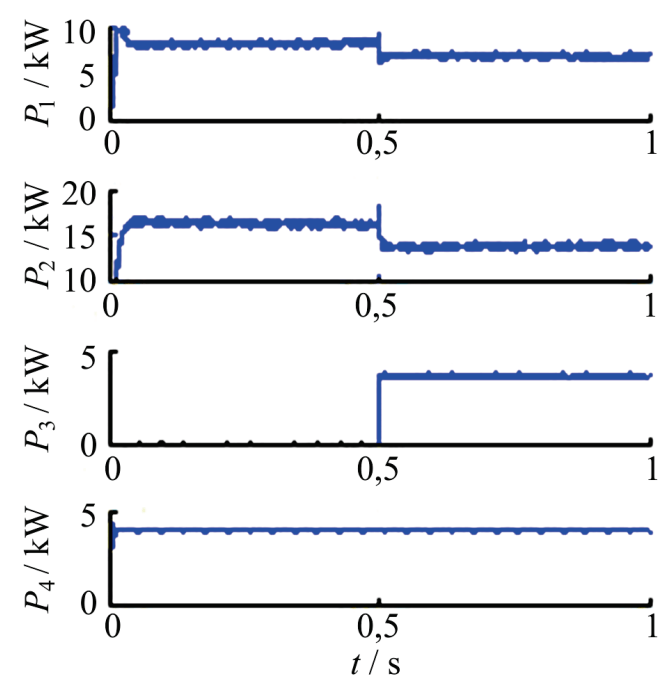

(b) Incorporated into the micro grid using grid-connected controller

Figs. $12 \mathrm{~b}$ and $13 \mathrm{~b}$. So the injection current $I$ shows excess smoothness of $\mathrm{DG}_{3}$ to the micro grid, and no large current rush is produced to the micro power grid system as in Fig. $14 \mathrm{~b}$. Furthermore, the large power rush is not created for either the other DGs active power $P_{1}, P_{2}, P_{3}, P_{4}$ or the reactive power $Q_{1}, Q_{2}, Q_{3}, Q_{4}$ at $0,5 \mathrm{~s}$ as shown in Figs. 
$15 \mathrm{~b}$ and $16 \mathrm{~b}$, indicating that the power source $\mathrm{DG}_{3}$ can connect to the micro grid system smoothly. The important load voltage fluctuations $U_{1}$ and $U_{2}$ are almost approximately equal to zero when power source $\mathrm{DG}_{3}$ is reconnected to the micro grid moment through the synchronous grid-connected controller. The simulation
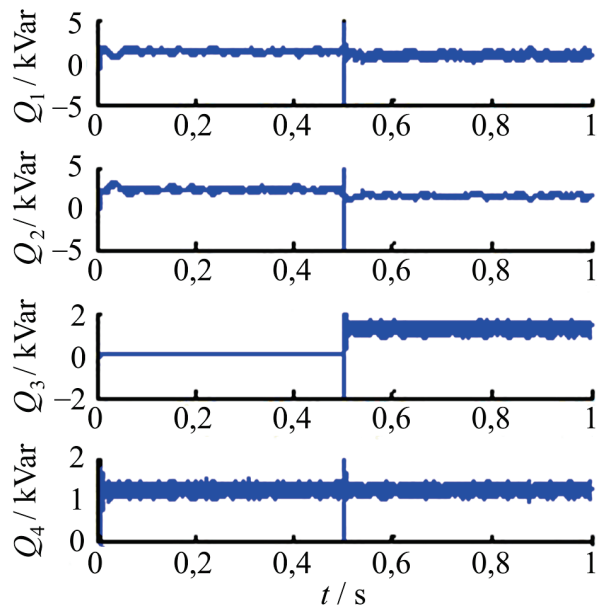

(a) Directly incorporated into the micro grid

figure is shown in Fig. 17b. This indicats that the method of $\mathrm{DG}_{3}$ being connected to the micro grid by the synchronous grid-connected controller can satisfied the stability and reliability requirements of the important load power supply.
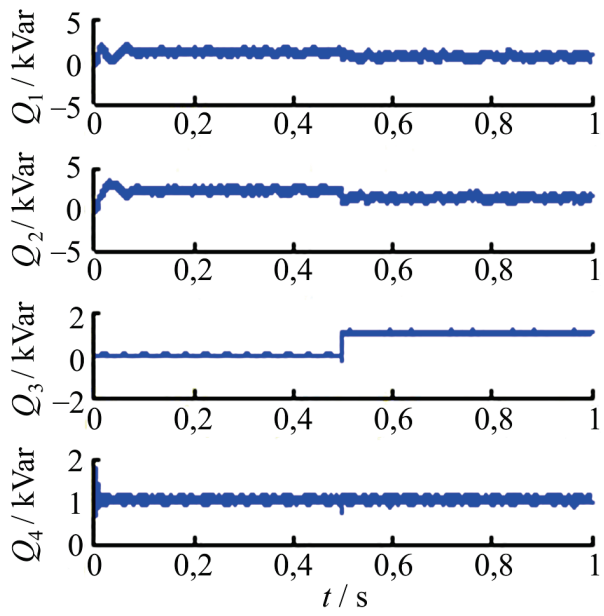

(b) Incorporated into the micro grid using grid-connected controller Figure 16 The waveform of DG reactive power
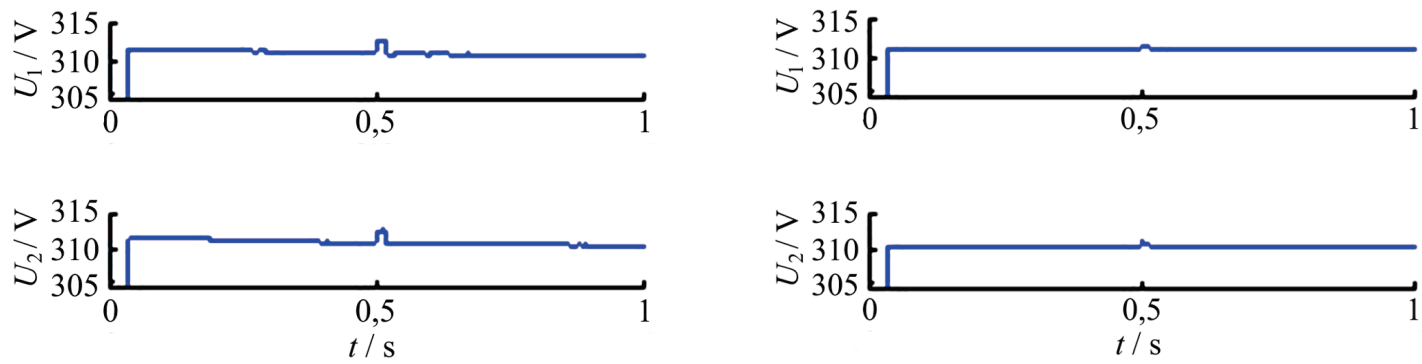

(a) Directly incorporated into the micro grid

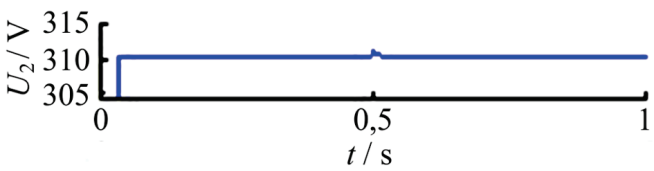

(b) Incorporated into the micro grid using grid-connected controller Figure 17 The voltage waveform of important load 1 and load 2

\section{Conclusion}

This study applies the parallel synchronous gridconnected controller to the wind-solar-storage micro grid power system based on voltage space vector pulse width modulation technology. The theoretical analysis and simulation research validate that this parallel synchronous grid-connected controller can stabilize the power source type DG being reconnected to the grid very well. This can solve the grid impact problem of micro power being reincorporated into the micro grid, because of voltage amplitude, phase and frequency difference. These controls make the wind-solar-storage micro grid power system more conducive to realize real time control.

\section{Acknowledgements}

This paper comes from the wind-solar-storage and distributed generation system coordinated control strategy research of Inner Mongolia industrial university funds X201336.

\section{References}

[1] Lasseter, R. H., Smart distribution: Coupled microgrids. // Proc. IEEE. 99, (2011), pp. 1074 -1082. DOI: 10.1109/JPROC.2011.2114630
[2] Abdel-Rady Ibrahim Mohamed, Y.; Zeineldin, H. H.; Salama, M. M. A.; Seethapathy, R. Seamless Formation and Robust Control of Distributed Generation Microgrids via Direct Voltage Control and Optimized Dynamic Power Sharing. // IEEE Trans. Power Electronics. 27, (2012), pp. 1283 -1294. DOI: 10.1109/TPEL.2011.2164939

[3] Algrain, M. A multifaceted view of distributed generation systems and their impacts. // IEEE Power \& Energy Society General Meeting. 2009, pp. 1-5. DOI: 10.1109/pes.2009.5275572

[4] Radwan, A. A. A.; Mohamed, Y. A. I. Assessment and mitigation of interaction dynamics in hybrid AC/DC distribution generation systems. // IEEE Trans. Smart Grid, 3, (2012), pp. 1382 -1393. DOI: 10.1109/TSG.2012.2201965

[5] Bustos, C.; Watts, D.; Ren, H. MicroGrid Operation and Design Optimization with Synthetic Wind and Solar Resources. // IEEE Latin America Transactions. 10, (2012), pp. 1550-1562. DOI: 10.1109/TLA.2012.6187599

[6] Kroposki, B.; Lasseter, R.; Ise, T. et al. Making microgrids work. // IEEE Power and Energy Magazine Date. 6, 3(2008), pp. 40-53. DOI: 10.1109/MPE.2008.918718

[7] Nikkhajoei, H.; Lasseter, R. H. Distributed Generation Interface to the CERTS Microgrid. // IEEE Transactions on Power Delivery. 24, 3(2009), pp. 1598-1608. DOI: 10.1109/TPWRD.2009.2021040

[8] Lasseter, R. H.; Piagi, P. Microgrid: a conceptual solution. // Power Electronics Specialists Conference. 6, (2004), pp. 4285-4290. DOI: 10.1109/pesc.2004.1354758 
[9] Majumder, R. A Hybrid Microgrid With DC Connection at Back to Back Converters. // IEEE Trans. Smart Grid. 27, (2013), pp. 11-17.

[10] Dong, B.; Li, Y.; Zheng, Z.; Xu, L. Control strategies of micro grid with hybrid DC AC Buses. // Proceedings of the $14^{\text {th }}$ European Conference on Power Electronics and Applications / Birmingham, UK, 2011, pp. 1-8.

[11] Guerrero, J. M.; Loh, P. C.; Lee, T. L. et al. Advanced Control Architectures for Intelligent Microgrids-Part II: Power Quality, Energy Storage, and AC/DC Microgrids // IEEE Trans. Ind. Electron. (2013), pp. 1263 -1270. DOI: 10.1109/TIE.2012.2196889

[12] Ding, F.; Loparo, K. A.; Wang, C. Modeling and simulation of grid-connected hybrid AC/DC microgrid. // Proceedings of the IEEE Power and Energy Society General Meeting, 2012, pp. 22-26.

[13] Akbari, M.; Tafreshi, S. M. M.; Golkar, M. A. Voltage control of a hybrid ac/dc microgrid in stand-alone operation mode. // Proceedings of the IEEE PES Meeting on Innovative Smart Grid Technologies-India / Kollam, Kerala, India, 2011, pp. 363-367. DOI: 10.1109/isetindia.2011.6145342

[14] Zhou, Weiping; Wu, Zhengguo; Tang, Jinsong. The equivalent algorithm of SVPWM and the essence SVPWM of SPWM. // Proceedings of the CSEE. 26, 2(2006), pp. 133-137.

[15] Zhao, Rende; He, Yilang; Huang, Keyuan; et al. To improve the study of PWM rectifier load disturbance resistance. // Journal of Electrical Engineering Technology. 19, 6(2004), pp. 133-137.

[16] Dong, D.; Thacker, T.; Cvetkovic, I. et al. Modes of Operation and System-Level Control of Single-Phase Bidirectional PWM Converter for Microgrid Systems. // IEEE Trans. Smart Grid. 3(2013), pp. 1283 -1294.

[17] Li, Gang. PWM Algorithms for Indirect Matrix Converter. // Power Electronics and Motion Control Conference (IPEMC) / Harbin, China, 2012, pp. 1713-1717.

[18] Ling, Si; Chen, Ke; Zhang, Xin. A photovoltaic grid controller design and research of simulation. // Science \& Technology Information. 19, (2013), pp. 25-26.

[19] Yu, Feng; Hu, Guowen. A photovoltaic power generation to improve power quality Hooked up to the controller. // The smart grid and smart electrical equipment. 22, (2010), pp. $18-22$.

[20] Zhao, Guopeng; Liu, Jinjun. Parallel power quality controller error of current control research. // Proceedings of the CSEE. 30, 34(2010), pp. 57-62.

\section{Authors' addresses}

Hua Li

School of Electric Power College, Inner Mongolia University of Technology, Hohhot, China

The $9^{\text {th }}$ floor, unit 2, room 1102 of New District Hailar East Road Hutiejiayuan, Inner Mongolia Hohhot, China; Zip code: 010051 E-mail: lihua0806@qq.com

Yongfeng Ren, corresponding author

School of Electric Power College, Inner Mongolia University of Technology, Hohhot, China

The $9^{\text {th }}$ floor, unit 2, room 1102 of New District Hailar East Road Hutiejiayuan, Inner Mongolia Hohhot, China; Zip code: 010051 E-mail: renyongfeng@vip.sina.com

Le Li

Guodian united power technology company LTD

The $9^{\text {th }}$ floor, unit 2, room 1102 of New District Hailar East Road Hutiejiayuan, Inner Mongolia Hohhot, China; Zip code: 010051 E-mail: lile@gdupc.cn

\section{Zhenpeng Luo}

School of Electric Power College, Inner Mongolia University of Technology, Hohhot, China

The $9^{\text {th }}$ floor, unit 2, room 1102 of New District Hailar East Road Hutiejiayuan, Inner Mongolia Hohhot, China; Zip code: 010051 E-mail: 284226728@qq.com 